Article

\title{
Sustainable Cities and Healthy Cities: Are They the Same?
}

\author{
Kent E. Portney ${ }^{1, *}$ and Garett Thomas Sansom ${ }^{2}$ \\ ${ }^{1}$ Institute for Science, Technology and Public Policy, The G.H.W. Bush School of Government and Public Service, Texas A\&M \\ University, College Station, TX 77843, USA; E-Mail: kportney@tamu.edu \\ ${ }^{2}$ Institute for Sustainable Communities, Texas A\&M University, College Station, TX 77843, E-Mail: gsansom@arch.tamu.edu \\ * Corresponding author
}

Submitted: 2 May 2017 | Accepted: 31 August 2017 | Published: 25 September 2017

\begin{abstract}
There is robust literature examining the wide array of public policies and programs cities pursue in order to try to become more sustainable. Whether the focus of such programs is explicitly on improving the bio-physical environment, climate protection and adaptation, energy efficiency, land use regulation, or any of a number of other targets, such programs often carry with them an expectation that the programs will contribute to improve the health of populations. While there is significant attention to asserting that such a relationship exists, or ought to exist, there have been no efforts to explicitly and empirically link city policies to health outcomes. This paper tackles this issue head-on, investigating the extent to which cities in the US that have the most aggressive sustainability initiatives exhibit better health outcomes than cities with less aggressive sustainability initiatives. Using data from the largest cities in the US, this paper presents evidence concerning the strength of this relationship, discusses the foundations for the relationship, and provides a discussion of the implications for urban planning, sustainability policies and for improving the health of populations.
\end{abstract}

\section{Keywords}

healthy cities; obesity; smart cities; sustainability; sustainability index; sustainable cities

\section{Issue}

This article is part of the issue "Smart Solutions for Sustainable Cities", edited by Tom Sanchez (Virginia Tech, USA), Ralph Hall (Virginia Tech, USA) and Nader Afzalan (Redlands University, USA).

(C) 2017 by the authors; licensee Cogitatio (Lisbon, Portugal). This article is licensed under a Creative Commons Attribution 4.0 International License (CC BY).

\section{Introduction}

An exhaustive amount of research exists on the connection between specific environmental exposures and lifestyle choices (Tremblay et al., 2011; van der Horst et al., 2007) and certain health outcomes. There also exists literature reviewing the implementation of sustainable policies within cities in the United States (Portney, 2013; Portney \& Berry, 2010). However, there is a dearth of projects exploring the connection between sustainability policies and population health within major US cities. There is little doubt that a central rationale underlying the sustainability programs and initiatives in cities is rooted in some conception of public health. What we mean by this is that advocates of urban sustainability often offer the argument that by pursuing sustainabil- ity policies, cities will improve the health of their populations. The dominant view of sustainability, of course, is related to the quality of the biophysical environment, and cities' policies in pursuit of sustainability promise to improve that environment. But many advocates of urban sustainability go beyond efforts to protect and improve that environment, suggesting that the ultimate purpose is to improve the health and wellbeing of cities' respective populations.

Curiously, while there are many studies of cities' sustainability policies and programs, there are very few efforts to empirically tie these policies to the health of the population. Likewise, public health interventions that have been implemented to improve the health status of certain populations have typically not pursued sustainability programs as possible avenues for improving con- 
ditions. In short, we know much more about why some cities are more likely to pursue sustainability policies than we know about what these policies achieve. This project sets to explain the conceptual connections between sustainability policies and programs on one hand and the health of the population on the other. We then examine the empirical patterns of relationship between sustainability and population health across the largest cities in the U.S. Far from being definitive, this paper seeks to begin a conversation about what the health of the population will look like as well as what results seem to be produced when cities adopt and implement sustainability policies. This research specifically examines the prevalence of obesity within urban centers as a public health concern as curbing the rise in obesity has proven to be particularly challenging when utilizing standard public health intervention strategies (Segal, Rayburn, \& Martin, 2016, pp. 108-116). Embedded in this is a call for better city-specific measures of health statistics to facilitate future research.

\section{Sustainability as a Strategy for Addressing Current Chronic and Degenerative Diseases}

The idea that sustainability can be an appropriate vehicle for advancing public health interventions and the health of populations is certainly not new. Although earlier conceptions of this linkage focused mainly on the pursuit of sustainability as a way of reducing exposures to environmental hazards and toxics, more recent conceptions have been somewhat more expansive. The silver lining for many chronic ailments-such as cardiovascular disease, cancer, stroke, and diabetes-is that they are often preventable through nonclinical lifestyle changes (Penedo \& Dahn, 2005; Sato, Nagasaki, Nakai, \& Fushimi, 2016). However, there are serious conditions, both chronic and acute, that are associated with environmental exposures. Many residence of environmental justice communities, areas in which pollution is ubiquitous, find that they cannot avoid exposures to these pollutants as they are continuously present in the places they live and work (Bryant, 1992; Bullard, 2000; Morello-Frosch, Pastor, \& Sadd, 2001). The goal of adopting sustainable policies should explicitly address environmental and public health concerns to create healthier populations.

The rise in obesity rates within the United States paints a concerning picture for the future health of citizens. While obesity itself is not a health condition, research has shown that obesity is highly correlated to a number of expensive and potentially debilitating diseases, such as type II diabetes and colon cancer, in additional to emotional and social harm (Mokdad et al., 2003; Scott et al., 2008). Many factors have contributed to the rise of obesity in the western world. Lifestyle changes, such as living a sedentary lifestyle and overconsuming calorie dense foods, have become more common and have been shown to be linked to obesity (Manson, Skerrett, Greenland, \& Vanltallie, 2004). Further, the genetic composition of individuals can increase, or decrease, the risk of obesity (Barness, Opitz, \& Gilbert-Barness, 2007). In one cross sectional study using a nationally representative sample, researchers Kirby, Liang, Chen and Wang (2012) found that demographic information, such as race, sex, and employment type, showed a marked difference in obesity rates. Despite a large and growing body of literature no efforts have been successful in stopping this increasing trend on a national, state, or community scale. The failure of standard approaches to health interventions is illustrative for the need to adopt a new approach with sustainability in mind.

The connection between the pursuit of sustainability and achievement of public health goals in American cities has been well documented. Arguing that the connection is finding its way into practice, for example, Jason Corburn (2009) describes how the city of San Francisco has made significant strides in planning for sustainability in a way that readily accommodates public health and healthy living goals. His vision is that decentralized and resident-engaged planning facilitates the goals of achieving a more sustainable and equitable biophysical environment and public health outcomes.

Under the guidelines proposed by Corburn (2009), a more inclusive approach that positively connects the scientific, social, and political institutions will move towards healthier citizens. This includes improving policies, and interventions, with the benefit of local knowledge through community-based organizations and local residents. Therefore, healthy city planning should be viewed as healthy urban planning and readily connect the two into a more holistic approach to improve the health and lives of communities.

\section{Sustainable Cities in the U.S.}

The concept and practice of sustainable cities has been well researched in the U.S. Over the last 20 years, many cities have created significant sustainability plans, often as a result of their long-term strategic planning processes. By one estimate, by 2015 at least 50 of the largest 55 cities operate under a sustainability plan (Portney, 2013, p. 23). Most such cities engage in making public policies and managing city programs in ways that are consistent with trying to achieve greater sustainability, environmental quality and equity, and energy efficiency. Cities that seem to take the pursuit of sustainability more seriously have been shown to engage in efforts to plan and implement policies on renewable energy and climate protection, public transit, waste reduction, water conservation, protection of environmentally-sensitive land, green building, and dozens of other programs. Many of these cities, particularly in the context of cities' sustainability indicators initiatives, implicitly include efforts to measure a variety of public health outcomes. In many cities, specific programs have been created to affect public health outcomes, from reducing exposures to toxics through asbestos and lead paint remediation, to encour- 
aging exercise through bicycle ridership programs, to promoting locally-grown produce through community gardens and farmers markets, and many other programs. We refer to these as implicit health programs because the connection between the programs and public health or nutrition is rarely discussed. There are a few notable exceptions. As noted earlier, Corburn (2009) has documented such efforts in San Francisco. Sustainable cities programs with implicit public health content have been made in a wide array of cities including Seattle, Portland, New York City, Philadelphia, Chicago, Los Angeles, and many others. Indeed, some sustainability plans adopted by cities contain explicit chapters dedicated to achieving targeted public health outcomes.

The idea that when cities pursue sustainability as a matter of public policy they are effectively improving the health of their populations is tantalizing. While there is evidence that sustainability policies do in fact protect and improve the quality of the biophysical environment, neither the policies nor the environmental outcomes have been shown to be related to public health. Despite the logic of the expectation that these should be related, the evidence is lacking. So this analysis examines the simple hypothesis, implied by the logic, that U.S. cities electing to aggressively pursue sustainability policies and programs have healthier populations than cities electing not to pursue sustainability. Specifically, we expect sustainable cities to have smaller numbers of people with chronic health problems.

\section{Examining the Largest Cities in the United States}

The analysis presented here examines the empirical linkages between city sustainability policies, programs, and outcomes on one hand and public health outcomes on the other. The focus here is on the largest U.S. cities. The 55 largest U.S. cities, for which we have a sustainability policy and one public health outcome measure, collectively have approximately 15 percent of the population of the U.S. These cities and designated subsets provide the basis for assessing the empirical relationships.

\subsection{The Dependent Variables: Chronic Health Outcomes}

Measuring public health outcomes for cities presents a significant challenge. Very little city-specific data are available. The local data that are available tend to be for counties or for metropolitan areas rather than cities per se. For the purposes of this analysis, we rely on two measures of chronic public health issues. The first of these is the percentage of the adult population with body mass indexes (BMI) higher than 30 in 2013, representing a measure of chronic obesity, in the county where the city resides. The second, also a measure of obesity and related issues, is an independent "Fattest Cities in America" Index created and reported by WalletHub for the largest 100 metropolitan areas (Bernardo, 2017). This index utilized obesity prevalence data collected through the Center for Disease Control and Prevention (2017) Behavioral Risk Factor Surveillance System Survey initiative and The University of Wisconsin Population Health Institute (2017) "County Health Rankings \& Roadmap". This index uses several dimensions, including obesity, weightrelated health problems, and environmental conditions. We use these "Fattest Cities in America Index" scores for the metropolitan areas containing 54 of the 55 largest U.S. cities (no Index value is reported for Fresno, California). This Index is a composite of some 17 specific indicators derived from a variety of official sources, including the percent of overweight and obese adults, teenagers, and children, projected obesity rates, percent of adults who are physically active, who eat fewer than one serving of fruits and vegetables a day, who have high serum cholesterol, high blood pressure, and heart disease. It also includes three indicators of healthy lifestyles. These indicators are weighted and combined into a single index score for each metropolitan area where the "fattest city" (Jackson, Mississippi) has a score of 84.93 and the least fat city (Seattle-Tacoma-Bellevue, Washington) has a score of 51.93. Among the 54 cities analyzed here, the "fattest" is Memphis, Tennessee (the second fattest city overall) with a score of 82.78 , and the leanest is Seattle.

These county and metropolitan area data are but an approximation of the health of the residents of the city, but do provide at least some insight into the health of the people in the respective areas. For the BMI measure, we simply obtained information for the county (or largest county) in which each city exists. Some cities, such as Philadelphia, are coterminous with the county. Many others, such as Jacksonville, Florida, or Boston, Massachusetts, have counties that are only slightly larger than the cities themselves. A small number of cities are split between two or three counties, and for the purposes of this analysis, we used health data for the largest county. A few cities share a county, such as Los Angeles and Long Beach, California, both of which are in Los Angeles County, and Arlington and Fort Worth, Texas, both of which are in Tarrant County. In these cases, both cities are characterized by the same county data. And New York City consists of multiple counties or boroughs, so the BMI data for this city represents an average across all the boroughs. The correlation between these two measures across all 54 cities is .673 (significant at the .000 level), indicating that they are likely measuring a common underlying health condition.

\subsection{The Independent Variables: City Sustainability Policies and Results}

The estimation of the effects of city sustainability on public health outcomes requires measures of urban sustainability. Here we rely on three independent measures. We employ three measures for the simple reason that this represents a safeguard against the empirical results being an artifact of a single measure, or of a particular group of cities for which any particular measure is avail- 
able. First, we rely on the Sustainable Cities Policies Index created by and reported in Portney (2013), computed for the 55 largest U.S. cities based on the policies and programs of cities in 2011. This Index focuses on measuring the amount of public policy effort cities make in the pursuit of sustainability, and does not attempt to measure any outcomes from those policies. It represents a composite additive index of the number of some 38 different specific sustainability-related policies or programs that each city has adopted and implemented. These index values range from 7 in Wichita, Kansas to 35 in Seattle, Washington, Portland, Oregon, and San Francisco, California. In other words, Seattle, Portland, and San Francisco have adopted and implemented 35 of the 38 possible programs and policies, while Wichita has adopted and implemented on 7.

Two additional measures of sustainability are included here despite the fact that these are reported for smaller numbers of cities. These are included in order to provided added evidence that the Sustainable Cities Policies Index measure has some level of validity, and the results that follow are not simply an artifact of this Index. So the second measure of sustainability is the Siemens Green Cities Index (Economist Intelligence Unit, 2011), measuring both environmental quality and city commitment to sustainability programs, for 21 large U.S. cities. This Index, reported for the year 2011, measures a mixture of 30 different environmental quality and sustainability program characteristics. The overall Green City Index values range from 83.8 in San Francisco to 28.4 in Detroit, and provide relative assessments of how well each city performs on some 16 different categories including carbon emissions, energy consumption, land use, building efficiency, transportation efficiency, water quality, waste, air quality, and environmental governance. Higher values represent better environmental performance.

Third, we include the SustainLane Sustainable Cities Score for 2007, measuring characteristics of the natural and built environment, for 49 large U.S. cities. The SustainLane Indexes were computed for large metropolitan areas based on 15 different measures of the quality of the environment and the quality of life in an effort to measure in an objective way how sustainable cities are (Karlenzig, Marquardt, White, Yaseen, \& Young, 2007). The resulting index includes air quality, city innovation, commuting to work, energy consumption and conservation, green building, affordable housing, local food and agriculture, traffic congestion, risk of natural disasters, water quality, and other characteristics. Among the fifty cities, Portland, Oregon had the highest sustainability score (85.08), and Columbus, Ohio the lowest (32.5).

Table 1 provides a side-by-side comparison of what the three measures of the key dependent variable, sustainability, take into consideration. These three measures are quite closely correlated, as shown in Table 2. Since the Siemens Index is reported only for 21 of the largest U.S. cities, and the SustainLane Index is reported for only 49 cities, these correlations are based on the smaller number of cities rather than the full group of the 55 largest cities. Analysis of the Sustainable Cities Policies Index, presented later, is based on the full set of the 55 largest cities ( 54 cities when the "Fattest Cities in America" Index is used as the dependent variable). These high correlations among the three sustainability measures provide strong evidence that they are all measuring the same or a very similar underlying dimension of sustainability, and that there is a high degree of validity to each sustainability measure.

\section{Analysis}

The expectation that these measures of city sustainability should be related to public health outcomes is examined in Table 2, which reports the bivariate correlations. It is immediately evident that these correlations are extremely high for all three measures of sustainability and both measures of public health. Among the cities studied here, there is a very strong tendency for those with aggressive sustainability programs and efforts to have considerably healthier populations with respect to obesity. Clearly, the results are not dependent on the measure of sustainability. Whether measured by the Sustainable Cities Policies Index for all 55 cities, or just the 21 cities included in the Siemens Green Cities Index, or the Green Cities Index itself, or the SustainLane Index, the patterns represented by the bivariate correlations is the same. Cities that are more aggressive in the pursuit of sustainability demonstrated better outcomes on the two measures. The scattergram in Figure 1 makes the bivariate relationship between the Sustainable Cities Policies Index and the percentage of the adult population with a BMI over 30 very clear. There is little question that among the 55 largest U.S. cities, those that have made policy commitments to the pursuit of sustainability have adult populations with lower obesity rates.

The bivariate analyses provide strong hints that sustainable cities programs may well be linked to public health outcomes. However, this relationship could simply be the result of a set of spurious relationships where both the health outcomes and the sustainability programs are the result of other influences. Before making an inference that sustainability programs contribute to positive public health outcomes, an effort needs to be made to rule out possible basic spurious influences. The analysis here focuses on several specific population characteristics that might play a role. These characteristics are the level of income, here measured as per capita income in 2009 , the proportion of the population that is 65 years of age or older, and the percentage of the population that is African American. Each of these characteristics could represent a spurious influence on the obesity outcomes. While many demographic variables have been shown to be associate with increased rates of obesity; race, socioeconomic factors, and age are the primary drives that could be adjusted for within 
Table 1. Comparison of three measures of city sustainability.

\begin{tabular}{|c|c|c|}
\hline $\begin{array}{l}\text { Sustainable Cities Policies Index } \\
\text { Has the city adopted and implemented } \\
\text { a policy to: }\end{array}$ & $\begin{array}{l}\text { Siemens Green Cities Index } \\
\text { At what level is the city's: }\end{array}$ & $\begin{array}{l}\text { SustainLane Sustainable Cities Score } \\
\text { At what level is the city's: }\end{array}$ \\
\hline $\begin{array}{l}\text { 1. Pursue targeted or cluster green } \\
\text { economic development }\end{array}$ & $\begin{array}{l}\text { 1. Total } \mathrm{CO}_{2} \text { emissions per dollar } \\
\text { of GDP }\end{array}$ & 1. City commuting to work \\
\hline 2. Develop and eco-industrial park & 2. Total $\mathrm{CO}_{2}$ emissions per capita & 2. Regional public transit ridership \\
\hline 3. Re-develop at least one brownfield & 3. $\mathrm{CO}_{2}$ emissions strategy & $\begin{array}{l}\text { 3. Metropolitan street and freeway } \\
\text { congestion }\end{array}$ \\
\hline $\begin{array}{l}\text { 4. Develop eco-villages, urban infill } \\
\text { housing, or transit oriented housing }\end{array}$ & $\begin{array}{l}\text { 4. Total electricity consumption per } \\
\text { dollar of GDP }\end{array}$ & 4. Air quality \\
\hline $\begin{array}{l}\text { 5. Use zoning to delineate } \\
\text { environmentally sensitive growth or } \\
\text { protected areas }\end{array}$ & $\begin{array}{l}\text { 5. Total electricity consumption per } \\
\text { capita }\end{array}$ & 5. Tap water quality \\
\hline $\begin{array}{l}\text { 6. Plan land use comprehensively to } \\
\text { include environmental issues }\end{array}$ & $\begin{array}{l}\text { 6. Commitment to promoting green } \\
\text { energy }\end{array}$ & 6. Solid waste diversion \\
\hline $\begin{array}{l}\text { 7. Provide tax or fee incentives for } \\
\text { environmentally-friendly development }\end{array}$ & $\begin{array}{l}\text { 7. Standardized percent of city area } \\
\text { devoted to greenspace }\end{array}$ & 7. Land use planning \\
\hline $\begin{array}{l}\text { 8. Operate or sponsor intra-city mass } \\
\text { transit }\end{array}$ & $\begin{array}{l}\text { 8. Population density (number of } \\
\text { inhabitants per squarer mile) }\end{array}$ & 8.City innovation \\
\hline 9. Place limits on downtown parking & $\begin{array}{l}\text { 9. Commitment to improving amount } \\
\text { of greenspace }\end{array}$ & 9. Housing affordability \\
\hline 10. Create intra-city HOV car pool lanes & $\begin{array}{l}\text { 10. Commitment to containing urban } \\
\text { sprawl and brownfield redevelopment }\end{array}$ & 10. Natural disaster risk \\
\hline $\begin{array}{l}\text { 11. Establish alternatively-fueled city } \\
\text { vehicle program (green fleet) }\end{array}$ & $\begin{array}{l}\text { 11. Number of LEED-certified green } \\
\text { buildings }\end{array}$ & 11. Energy and climate change policy \\
\hline $\begin{array}{l}\text { 12. Create a bicycle ridership or bike- } \\
\text { sharing program }\end{array}$ & $\begin{array}{l}\text { 12. Requirement for energy audits } \\
\text { and monitoring }\end{array}$ & $\begin{array}{l}\text { 12. Local food and agriculture } \\
\text { availability }\end{array}$ \\
\hline $\begin{array}{l}\text { 13. Establish a household solid waste } \\
\text { recycling program }\end{array}$ & $\begin{array}{l}\text { 13. Commitment to retro-fitting } \\
\text { building for energy efficiency }\end{array}$ & 13. Green economy \\
\hline 14. Provide industrial recycling & $\begin{array}{l}\text { 14. Commuting to work with public } \\
\text { transit, walking, or biking }\end{array}$ & $\begin{array}{l}\text { 14. Knowledge base and } \\
\text { communications }\end{array}$ \\
\hline $\begin{array}{l}\text { 15. Create hazardous waste recycling } \\
\text { program }\end{array}$ & $\begin{array}{l}\text { 15. Commitment to providing public } \\
\text { transit options }\end{array}$ & 15. Green building \\
\hline $\begin{array}{l}\text { 16. Operate an air pollution reduction } \\
\text { program (e.g. VOC reduction) }\end{array}$ & 16. Average commute-to-work time & \\
\hline $\begin{array}{l}\text { 17. Mandate recycled product } \\
\text { purchasing by city government }\end{array}$ & $\begin{array}{l}\text { 17. Commitment to public transit } \\
\text { incentives }\end{array}$ & \\
\hline $\begin{array}{l}\text { 18. Create a superfund (non- } \\
\text { brownfield) site remediation program }\end{array}$ & $\begin{array}{l}\text { 18. Total water consumption in gallons } \\
\text { per person per day }\end{array}$ & \\
\hline 19. Engage in asbestos abatement & 19. Amount of water leakage & \\
\hline 20. Conduct lead paint abatement & $\begin{array}{l}\text { 20. Commitment to water quality from } \\
\text { main water sources }\end{array}$ & \\
\hline $\begin{array}{l}\text { 21. Reduce pesticide use (integrated } \\
\text { pest management) }\end{array}$ & 21. Stormwater management plan & \\
\hline $\begin{array}{l}\text { 22. Create urban garden/ sustainable } \\
\text { food system or agriculture program }\end{array}$ & 22. Amount of solid waste recycled & \\
\hline
\end{tabular}


Table 1. Comparison of three measures of city sustainability. (Cont.)

\begin{tabular}{|c|c|}
\hline $\begin{array}{l}\text { Sustainable Cities Policies Index } \\
\text { Has the city adopted and implemented } \\
\text { a policy to: }\end{array}$ & $\begin{array}{l}\text { Siemens Green Cities Index } \\
\text { At what level is the city's: }\end{array}$ \\
\hline 23. Mitigate the heat island effect & 23. Commitment to waste reduction \\
\hline 24. Green building program & 24. NOx emissions per person per year \\
\hline $\begin{array}{l}\text { 25. Green affordable/low income } \\
\text { housing program }\end{array}$ & 25. $\mathrm{SO}_{2}$ emissions per person per year \\
\hline $\begin{array}{l}\text { 26. Commit to renewable energy by } \\
\text { city government (renewable energy } \\
\text { portfolio) }\end{array}$ & 26. PM10 emission per person per year \\
\hline $\begin{array}{l}\text { 27. Create an energy conservation } \\
\text { program }\end{array}$ & $\begin{array}{l}27 . \text { Commitment to air emission } \\
\text { reduction }\end{array}$ \\
\hline $\begin{array}{l}\text { 28. Offer alternative (renewable) } \\
\text { energy to consumers }\end{array}$ & 28. Commitment to green action plan \\
\hline 29. Conserve water & $\begin{array}{l}\text { 29. Extensiveness of environmental } \\
\text { management }\end{array}$ \\
\hline $\begin{array}{l}\text { 30. Operate a sustainability indicators } \\
\text { project in the previous five years }\end{array}$ & $\begin{array}{l}\text { 30. Involvement of general public in } \\
\text { monitoring environmental } \\
\text { performance }\end{array}$ \\
\hline
\end{tabular}

31. Assess progress toward achieving indicators within previous five years

32. Create an action plan to achieve sustainability indicators

33. Establish a single city office, agency, or person responsible for implementing sustainability initiatives

34. Integrate sustainability goals into a citywide comprehensive or general plan

35. Involve city, county, and metropolitan planning council in sustainability decisions

36. Explicitly involved mayor/chief executive officer in sustainability decisions

37. Involve the business community in sustainability decisions

38. Involve the general public in sustainability planning

this analysis (Wang \& Beydoun, 2007). Geographic regions have been shown to produce disparate rates of obesity, a phenomenon this analysis hopes to further understanding in. Individual-level data, such medical or job history, was outside the ability of this ecological research. Cities with higher incomes, with smaller African American populations, and with larger elderly populations should have better health outcomes-smaller numbers of people with high BMI and better scores on the
SustainLane Sustainable Cities Score At what level is the city's: 


\section{COGITATIO}

Table 2. Bivariate correlations between Sustainable Cities measures and Health Outcomes measures.

\begin{tabular}{|c|c|c|}
\hline Sustainable Cities Measures & $\begin{array}{c}\% \text { of adults with BMI } \\
\text { over } 30(2013)\end{array}$ & $\begin{array}{c}\text { "Fattest Cities in } \\
\text { America" Index (2016) }\end{array}$ \\
\hline Sustainable Cities Policies Index (2011) & $\begin{array}{c}-.452 * * \\
\text { ( } n=55 \text { cities })\end{array}$ & $\begin{array}{c}-.356^{* *} \\
(\mathrm{n}=54 \text { cities })\end{array}$ \\
\hline Siemens Green Cities Index (2011) & $\begin{array}{c}-.356^{* *} \\
(\mathrm{n}=21 \text { cities })\end{array}$ & $\begin{array}{c}-.405^{*} \\
(\mathrm{n}=21 \text { cities })\end{array}$ \\
\hline Sustainable Cities Policies Index (2011) for 21 Siemens Cities & $\begin{array}{c}-.637^{* *} \\
(\mathrm{n}=21 \text { cities })\end{array}$ & $\begin{array}{c}-.414^{*} \\
(\mathrm{n}=21 \text { cities })\end{array}$ \\
\hline SustainLane Sustainable Cities Index (2007) & $\begin{array}{c}-.521^{*} \\
(\mathrm{n}=49 \text { cities })\end{array}$ & $\begin{array}{c}-.628^{* *} \\
(\mathrm{n}=49 \text { cities) }\end{array}$ \\
\hline
\end{tabular}

${ }^{* p}<0.05 ; * p<0.01$

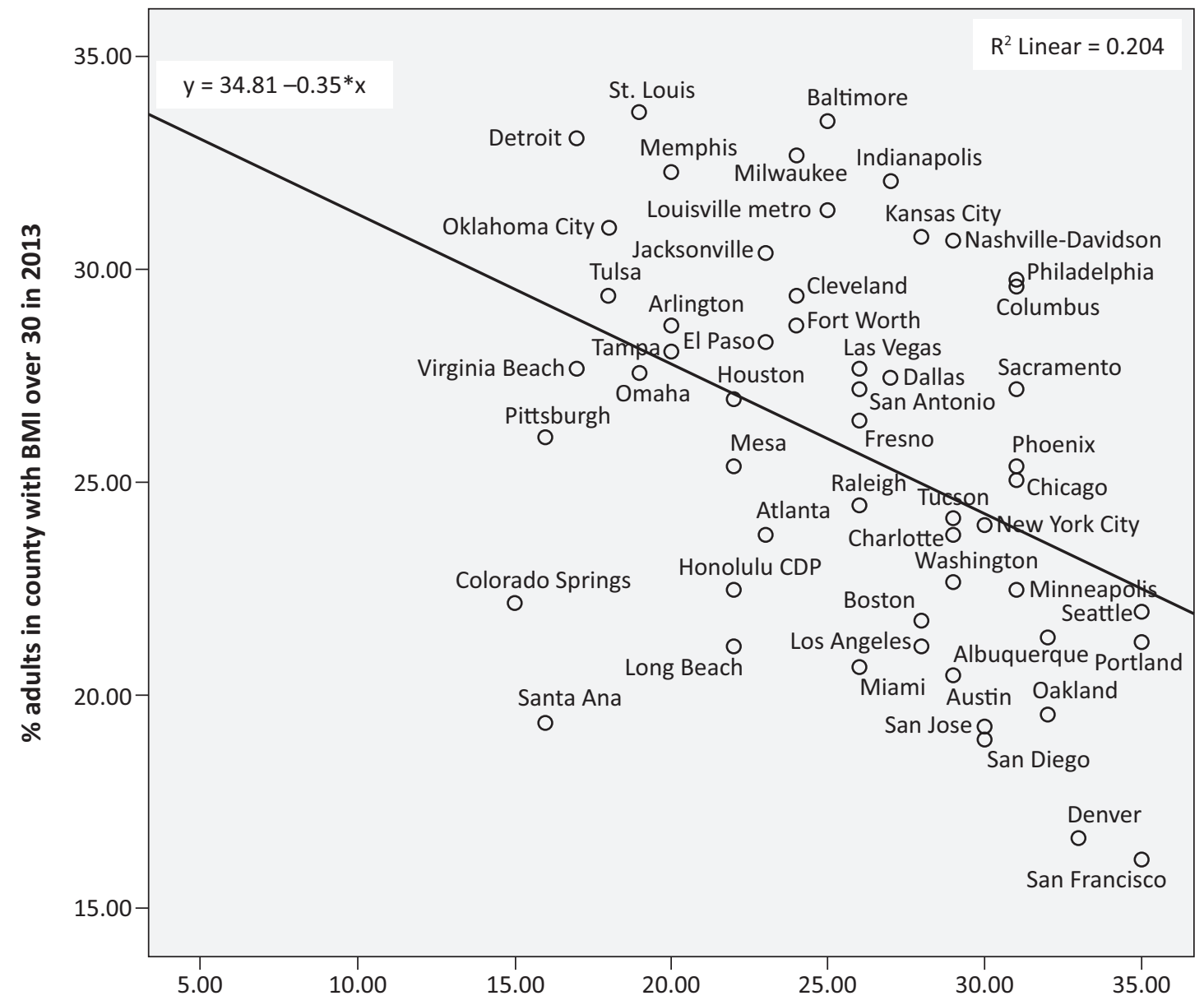

Sustainability Cities Policy Index for 2011

Figure 1. Scattergram showing the relationship between the Sustainable Cities Policies Index and the percent of adults with BMI over 30 for the 55 largest U.S. cities.

tainability policies will continue to present better health outcomes.

Tables 3 and 4 provide the results of ordinary least squares regression analyses. Table 3 presents three sets of regression results where the dependent variable is the percentage of people with BMI over 30. Table 4 presents regression results using the Fattest Cities index value as the dependent variable. Explanatory variables account for measures of city sustainability, per capita income, the size of the African American population, and the size of the elderly (65 years and older) population. Each table presents three models where Model 1 uses the Sustainable Cities Policies Index, Model 2 uses the Siemen's Green Cities Index, and Model 3 uses the SustainLane Sustainable Cities index as alternative explanatory variables. 
Table 3. OLS regression results showing the effects of sustainability on obesity levels (percent with BMI over 30) in large U.S. cities.

\begin{tabular}{|c|c|c|c|c|c|c|}
\hline \multirow{2}{*}{ Independent Variables } & \multicolumn{2}{|c|}{ Model 1} & \multicolumn{2}{|c|}{ Model 2} & \multicolumn{2}{|c|}{ Model 3} \\
\hline & $\begin{array}{c}\beta \\
\text { (SE) }\end{array}$ & $\begin{array}{c}\text { Standardized } \\
\text { Beta }\end{array}$ & $\begin{array}{c}\beta \\
\text { (SE) }\end{array}$ & $\begin{array}{c}\text { Standardized } \\
\text { Beta }\end{array}$ & $\begin{array}{c}\beta \\
\text { (SE) }\end{array}$ & $\begin{array}{c}\text { Standardized } \\
\text { Beta }\end{array}$ \\
\hline Sustainable Cities Policies Index & $\begin{array}{c}-.172 \\
(.08)\end{array}$ & $-.221^{* *}$ & - & - & - & - \\
\hline Siemens Green Cities Index & - & - & $\begin{array}{l}-.084 \\
(.088)\end{array}$ & -.262 & - & - \\
\hline SustainLane Sustainable Cities Index & - & - & - & - & $\begin{array}{l}-.114 \\
(.039)\end{array}$ & $-.318^{* *}$ \\
\hline Percent African American population & $\begin{array}{l}.106 \\
(.024)\end{array}$ & $.416 * *$ & $\begin{array}{c}.082 \\
(.045)\end{array}$ & .358 & $\begin{array}{c}.094 \\
(.023)\end{array}$ & $.378 * *$ \\
\hline Percent Aged 65 or older & $\begin{array}{l}.146 \\
(.172)\end{array}$ & .079 & $\begin{array}{l}-.178 \\
(.246)\end{array}$ & -.098 & .143 & .072 \\
\hline Per capita income & $\begin{array}{c}.000 \\
(.000)\end{array}$ & $-.406^{* *}$ & $\begin{array}{c}.000 \\
(.000)\end{array}$ & -.378 & $\begin{array}{c}.000 \\
(.000)\end{array}$ & $-.414^{* *}$ \\
\hline Constant & $\begin{array}{l}34.6^{* *} \\
(3.04)\end{array}$ & - & $\begin{array}{c}35.7^{* *} \\
(5.6)\end{array}$ & - & $\begin{array}{c}36.7^{* *} \\
(2.9)\end{array}$ & - \\
\hline Adjusted $\mathrm{R}^{2}$ & \multicolumn{2}{|r|}{$.537^{* *}$} & \multicolumn{2}{|r|}{$.639 * *$} & \multicolumn{2}{|c|}{$.616^{* *}$} \\
\hline$N$ & \multicolumn{2}{|r|}{55} & \multicolumn{2}{|r|}{21} & \multicolumn{2}{|c|}{49} \\
\hline
\end{tabular}

${ }^{*} p<0.05 ;{ }^{* *} p<0.001$

Table 4. OLS regression results showing the effects of sustainability on obesity levels (Fattest Cities in America Index) in large U.S. cities.

\begin{tabular}{|c|c|c|c|c|c|c|}
\hline \multirow{2}{*}{ Independent Variables } & \multicolumn{2}{|c|}{ Model 1} & \multicolumn{2}{|c|}{ Model 2} & \multicolumn{2}{|c|}{ Model 3} \\
\hline & $\begin{array}{c}\beta \\
\text { (SE) }\end{array}$ & $\begin{array}{c}\text { Standardized } \\
\text { Beta }\end{array}$ & $\begin{array}{c}\beta \\
\text { (SE) }\end{array}$ & $\begin{array}{c}\text { Standardized } \\
\text { Beta }\end{array}$ & $\begin{array}{c}\beta \\
\text { (SE) }\end{array}$ & $\begin{array}{c}\text { Standardized } \\
\text { Beta }\end{array}$ \\
\hline Sustainable Cities Policies Index & $\begin{array}{l}-.203 \\
(.168)\end{array}$ & -.155 & - & - & - & - \\
\hline Siemens Green Cities Index & - & - & $\begin{array}{l}.090 \\
(.192)\end{array}$ & .180 & - & - \\
\hline SustainLane Sustainable Cities Index & - & - & - & - & $\begin{array}{l}-.309 \\
(.078)\end{array}$ & $-.484 * *$ \\
\hline Percent African American population & $\begin{array}{l}.077 \\
(.051)\end{array}$ & .179 & $\begin{array}{l}.125 \\
(.099)\end{array}$ & .352 & $\begin{array}{l}.070 \\
(.047)\end{array}$ & .158 \\
\hline Percent aged 65 or older & $\begin{array}{l}-.624 \\
(.363)\end{array}$ & -.205 & $\begin{array}{l}-1.22 \\
(.538)\end{array}$ & $-.433^{*}$ & $\begin{array}{l}-.277 \\
(.380)\end{array}$ & -.079 \\
\hline Per capita income & $\begin{array}{l}-.001 \\
(.000)\end{array}$ & $-.397^{* *}$ & $\begin{array}{c}.000 \\
(.000)\end{array}$ & $-.486 *$ & $\begin{array}{c}.000 \\
(.000)\end{array}$ & $-.292 * *$ \\
\hline Constant & $\begin{array}{l}89.1^{* *} \\
(6.49)\end{array}$ & - & $\begin{array}{c}79.1^{* *} \\
(12.2)\end{array}$ & - & $\begin{array}{c}93.6^{* *} \\
(6.0)\end{array}$ & - \\
\hline Adjusted $\mathrm{R}^{2}$ & \multicolumn{2}{|r|}{$.294^{* *}$} & \multicolumn{2}{|r|}{$.290^{*}$} & \multicolumn{2}{|c|}{$.514^{* *}$} \\
\hline$N$ & \multicolumn{2}{|r|}{54} & \multicolumn{2}{|r|}{21} & \multicolumn{2}{|c|}{49} \\
\hline
\end{tabular}


These regression results provide additional evidence of the possible connection between city sustainability and the obesity measures by ruling out possible spurious or alternative explanations. OLS regression results are presented here for ease of interpretation. ${ }^{1}$ In Table 3, controlling for the demographics, the Sustainable Cities Policies Index and the SustainLane Sustainable Cities Index are both negatively significantly related to the percent of the adult population with a BMI above 30 . Cities with more aggressive sustainability programs and policies do indeed seem to be in counties with lower obesity rates. The Siemens' Index coefficient is not statistically significant. In Table 4, the relationships are not nearly as strong. Even so, the SustainLane index is strongly negatively related to the Fattest Cities in American Index, again suggesting that sustainable cities are in metropolitan areas with lower levels of health problems.

\section{Conclusions}

This project shows that obesity rates are inversely correlated with adoption and implementation of sustainability policies in the largest cities in the United States. The importance of these preliminary findings is underscored by the reality that very few public health interventions have been successful in reducing obesity rates with individuals or at the city, county, state, or national level. While public health efforts have shown success in protecting populations from the historical causes of mortality, such as the implementation of infrastructure systems that address sanitation needs, regulations to improve occupational safety, vaccination campaigns, as well as access to health care and screening programs, we are now faced with new challenges for which our standard model of care is ineffectual in meeting. The prevalence of obesity has risen to 35.6 percent in 2014. Obesity disproportionality affects Hispanic (42.5\%), and African American (48.1\%) communities (Ogden, Carroll, Fryar, \& Flegal, 2015). This trend is correlated with rises in cardiovascular disease, diabetes, and cancer.

Perhaps even more alarming is the increase in youth and adolescent chronic conditions. The World Health Organization (WHO) has declared that childhood obesity is one of the most serious public health issues in the 21st century. WHO researchers in the department of Nutrition for Health and Development have estimated that there are over 43 million obese preschool-aged children globally, a 60 percent increase since 1990 (De Onis, Blössner, \& Borghi, 2010). In the United States an estimated $17 \%$ of U.S. children and adolescents aged 2-19 years are obese and another $16 \%$ are overweight in 2014 , compared to only 5 percent obese and 10 percent overweight in 1974 (Fryar, Carroll, \& Ogden, 2016). While there was a modest drop in the prevalence of obesity in the United
States for adolescents from 2005-2012, in comparison to the prevalence in 2003 (Ogden, Carroll, Kit, \& Flegal, 2014), this has unfortunately reversed in more recent years as the prevalence of obesity has increased above the levels seen 2003 (Ogden et al., 2015). There are already an estimated 2.6 million deaths annually associated with obesity, as the current generation ages this number is expected to rise in the coming decades.

The analysis presented here is intended to highlight the potential for city sustainability policies and programs to be used as a vehicle for achieving desirable public health outcomes. We do not wish to argue that the analysis here represents a causal connection. Despite our efforts to measure the city sustainability programs at a time that precedes the public health outcomes measures, there is the possibility that the results here reflect some degree of endogeneity. The clearest limitations of this research revolve around the lack of data at the level of the individual. These results may well be reflective of a more complex set of relationships where healthier communities are more supportive of city sustainability policies and programs. Further, in the absence of most public health outcome data at the city level, as opposed to the county level presented here, constrains the inferences that can be made. Without individual data there were many variables which were unable to be controlled for in the analysis. Lopez (2014) identified that urban sprawl and location of an individual's residence was associated with obesity and should be account for. Further, dietary, lifestyle, and genetic composition, as well as gene-environment interactions were all unaccounted for in this research but have been shown to be determinants of obesity (Hruby et al., 2016). Further, the models only offer a small sample size and may suffer bias due to this. The results explicitly suggest that cities with stronger sustainability efforts are in counties and metropolitan areas with better health outcomes. Because of the fact that some, although not all, cities are in large counties, it is possible that it is better health outcomes in the areas of the counties outside of the city proper influencing this relationship. The results do, however, raise the possibility that city sustainability initiatives hold the promise to be an important vehicle for improving public health, in this case, obesity-related outcomes. We do not interpret the results here as reflecting coincidence. Future research will need to advance this line of inquiry by accounting for specific causal linkages and ruling out alternative explanations, presumably with benefit of more appropriate city-level (rather than county or metropolitan-level) health outcomes data.

\section{Conflict of Interests}

The authors declare no conflict of interests.

\footnotetext{
$\overline{1}$ Tests for multicollinearity and heteroscedasticity indicate assumptions of OLS regression have been satisfied. Results from ordinal regression (not shown but available from the authors) produced nearly identical conclusions, suggesting that the OLS results are not sensitive to possible violations of underlying assumptions.
} 


\section{References}

Barness, L. A., Opitz, J. M., \& Gilbert-Barness, E. (2007). Obesity: Genetic, molecular, and environmental aspects. American Journal of Medical Genetics Part A, 143(24), 3016-3034. doi:10.1002/ajmg.a.32035

Bernardo, R. (2017, March 22). 2017's fattest cities in America. WalletHub. Retrieved from https://wallet hub.com/edu/fattest-cities-in-america/10532/

Bryant, B. I., \& Mohai, P. (1992). Race and the incidence of environmental hazards. Boulder, CO: Westview Press.

Bullard, R. D. (2008). Dumping in Dixie: Race, class, and environmental quality (3rd ed.). Boulder, CO: Westview Press.

Centers for Disease Control and Prevention. (2017). Behavioral risk factor surveillance system survey data. Atlanta, GA: CDC.

Corburn, J. (2009). Toward the healthy city: people, places, and the politics of urban planning. Cambridge, MA: MIT Press.

De Onis, M., Blössner, M., \& Borghi, E. (2010). Global prevalence and trends of overweight and obesity among preschool children. The American Journal of Clinical Nutrition, 92(5), 1257-1264. doi:10.3945/ ajcn.2010.29786

Economist Intelligence Unit. (2011). US and Canada Green City Index: Assessing the environmental performance of 27 major US and Canadian cities. Munich. Siemens AG. Retrieved from http://www. siemens.com/press/pool/de/events/2011/corporate /2011-06-northamerican/northamerican-gci-reporte.pdf

Fryar, C. D., Carroll, M. D., \& Ogden, C. (2016). Prevalence of overweight and obesity among children and adolescents aged 2-19 years: United States, 1963-1965 through 2013-2014. Health E-Stats. Hyattsville, MD: National Center for Health Statistics.

Hruby, A., Manson, J. E., Qi, L., Malik, V. S., Rimm, E. B., Sun, Q., . . . Hu, F. B. (2016). Determinants and consequences of obesity. American Journal of Public Health, 106(9), 1656-1662. doi:10.2105/ AJPH.2016.303326

Karlenzig, W., Marquardt, F., White, P., Yaseen, R., \& Young, R. (2007). How green is your city? The SustainLane US city rankings. New York: New Society Publishers.

Kirby, J. B., Liang, L., Chen, H. J., \& Wang, Y. (2012). Race, place, and obesity: The complex relationships among community racial/ethnic composition, individual race/ethnicity, and obesity in the United States. American Journal of Public Health, 102(8), 1572-1578.

Lin, S. S., \& Kelsey, J. L. (2000). Use of race and ethnicity in epidemiologic research: Concepts, methodological issues, and suggestions for research. Epidemiologic Reviews, 22(2), 187-202.

Lopez, R. (2004). Urban sprawl and risk for being over- weight or obese. American Journal of Public Health, 94(9), 1574-1579. doi:10.2105/AJPH.94.9.1574

Manson, J. E., Skerrett, P. J., Greenland, P., \& Vanltallie, T. B. (2004). The escalating pandemics of obesity and sedentary lifestyle: A call to action for clinicians. Archives of Internal Medicine, 164(3), 249-258. doi:10.1001/archinte.164.3.249

Mokdad, A. H., Ford, E. S., Bowman, B. A., Dietz, W. H., Vinicor, F., Bales, V. S., \& Marks, J. S. (2003). Prevalence of obesity, diabetes, and obesityrelated health risk factors, 2001. Jama, 289(1), 76-79. doi:10.1001/jama.289.1.76

Morello-Frosch, R., Pastor, M., \& Sadd, J. (2001). Environmental justice and Southern California's "riskscape": The distribution of air toxics exposures and health risks among diverse communities. Urban Affairs Review, 36(4), 551-578. doi:10.1177/ 10780870122184993

Ogden, C. L., Carroll, M. D., Fryar, C. D., \& Flegal, K. M. (2015). Prevalence of obesity among adults and youth: United States, 2011-2014 (NCHS data brief, no. 219). Hyattsville, MD: National Center for Health Statistics.

Ogden, C. L., Carroll, M. D., Kit, B. K., \& Flegal, K. M. (2014). Prevalence of childhood and adult obesity in the United States, 2011-2012. Jama, 311(8), 806-814. doi:10.1001/jama.2014.732

Penedo, F. J., \& Dahn, J. R. (2005). Exercise and wellbeing: A review of mental and physical health benefits associated with physical activity. Current Opinion in Psychiatry, 18(2), 189-193.

Portney, K. E., \& Berry, J. M. (2010). Participation and the pursuit of sustainability in US cities. Urban Affairs Review, 46(1), 119-139. doi:10.1177/ 1078087410366122

Portney, K. E. (2013). Taking sustainable cities seriously (2nd ed.). Cambridge, MA: MIT Press.

Sato, Y., Nagasaki, M., Nakai, N., \& Fushimi, T. (2003). Physical exercise improves glucose metabolism in lifestyle-related diseases. Experimental Biology and Medicine, 228(10), 1208-1212. doi:10.1177/ 153537020322801017

Scott, K. M., Bruffaerts, R., Simon, G. E., Alonso, J., Angermeyer, M., de Girolamo, G., . . . Kessler, R. C. (2008). Obesity and mental disorders in the general population: Results from the world mental health surveys. International Journal of Obesity, 32(1), 192. doi:10.1038/sj.ijo.0803701

Segal, L. M., Rayburn, J., \& Martin, A. (2016). The state of obesity 2016: Better policies for a healthier America. Washington, DC: Trust for America's Health and Robert Wood Johnson Foundation. Retrieved from https://stateofobesity.org/files/stateofobesity2016. pdf

Signorello, L. B., Schlundt, D. G., Cohen, S. S., Steinwandel, M. D., Buchowski, M. S., McLaughlin, J. K., . . . Blot, W. J. (2007). Comparing diabetes prevalence between African Americans and Whites 
of similar socioeconomic status. American Journal of Public Health, 97(12), 2260-2267. doi:10.2105/ AJPH.2006.094482

Tremblay, M. S., LeBlanc, A. G., Kho, M. E., Saunders, T. J., Larouche, R., Colley, R. C., . . Gorber, S. C. (2011). Systematic review of sedentary behaviour and health indicators in school-aged children and youth. International Journal of Behavioral Nutrition and Physical Activity, 8(1), 98. doi:10.1186/1479-5868-8-98.

University of Wisconsin Population Health Institute. (2017). County health rankings national data [Data set]. Retrieved from http://www.countyhealth rankings.org/rankings/data van der Horst, K., Oenema, A., Ferreira, I., Wendel-Vos, W., Giskes, K., van Lenthe, F., \& Brug, J. (2006). A systematic review of environmental correlates of obesity-related dietary behaviors in youth. Health Education Research, 22(2), 203-226. doi:10.1093/ her/cyl069

Wang, Y., \& Beydoun, M. A. (2007). The obesity epidemic in the United States-Gender, age, socioeconomic, racial/ethnic, and geographic characteristics: A systematic review and meta-regression analysis. Epidemiologic Reviews, 29(1), 6-28. doi:10.1093/ epirev/mxm007

\section{About the Authors}

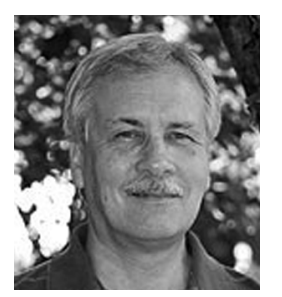

Kent E. Portney is Professor and Director of the Institute for Science, Technology, and Public Policy at the Bush School of Government and Public Service, Texas A\&M University, College Station, TX USA. He has written extensively on urban sustainability and is author of Taking Sustainable Cities Seriously: Economic Development, the Environmental and Quality of Life in American Cities, second edition (MIT Press, 2013).

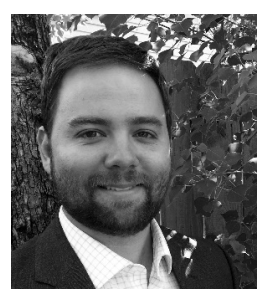

Garett Sansom is the Associate Director of the Institute for Sustainable Communities at Texas A\&M University, College Station, TX USA. His research has revolved around human health implications of the environment, urban planning, water security, and disaster preparedness. His empirical focus targets marginalized communities that experience environmental justice issues. 